\title{
Robert Simms, Anticipation and Anachrony in Statius' 'Thebaid', Bloomsbury Academic, London 2020, 208 pp.; ISBN 978-1-3500-8257-1
}

As Statius has always been a popular poet, frequently read and studied, the appearance of each new publication devoted to his oeuvre must lead straight to the question of what new contribution it makes to our knowledge of his works. The answer lies in the very title of the book by Robert Simms, a Classics teacher at Sage Ridge School in Reno, USA, which reveals the author's original and fresh approach. At the same time, however, it should be noted at the start that the title immediately narrows down the potential group of the book's readers to experts familiar with narratology, although it also means that readers from outside the circle of traditional classical philologists, who are intrigued by the application of modern research methods to ancient literature, may reach for it. In any case, using terms which are still hermetic in the title does not seem to be the correct choice, as Simms' book can be very much read and appreciated also without the knowledge of specialist terminology, as an incredibly inspiring study on narrative techniques used by Statius.

The work is divided into an introduction and eight chapters devoted to, generally chronological, issues - the episodes from Statius' poem. In the opening text ("Introduction: notum iter ad Thebas," pp. 1-13), Simms characterises the scope and aim of his work. His main goal, which he very successfully achieves, is to attempt to answer the question about the sources of the Thebaid's popularity already during the author's lifetime. The famous poet addressed in his epos the topic which was very familiar to the readers, who almost obsessively waited, as contemporary sources and Statius' own statements seem to attest, for a new and original interpretation of the myth. According to Simms, the main tool used by the Thebaid's author to achieve this goal was an anachronic approach to the plot and using techniques which are now termed anticipation, suspense and surprise. Simms explains the terms in the following way:

Anticipation, for the purpose of this study, is understood as the experience of the audience member or reader who enjoys through previous iterations familiarity with the constituent features of the narrative: the characters, their actions, canonical events, and so forth . . Suspense, on the other hand, will be taken to indicate the expectation of events where the outcome is uncertain, where familiarity with say Euripides' Phoenissae or any antecedent version is not helpful. And of course, we have surprise, where the outcome of events occurs contrary to what the audience might (have been led to) suspect (p. 9).

The terms defined in this way in a longer perspective naturally also refer to Aristotle's theoretical reflection on the art of composing a tragedy, as a result of which Simms' 
work, although it takes full advantage of modern narratology, deliberately maintains a constant link to the ancient tradition of literary criticism as well.

The next chapters of the work provide exemplifications of the author's main thesis, analysed according to the method he adopted. In Chapter 1 ("Beginning with the End," pp. 15-29), Simms shows how the poet, deciding to start the plot of his work in medias res, played according to the readers' expectations, their knowledge of various variants of the myth and the chronology of events which, as we have mentioned, he frequently presented in an anachronic way. In Chapter 2 ("Portentous Beginnings," pp. 31-47), the topic is further expanded on through an analysis of a number of supernatural events leading to the ultimate tragedy of the individual characters. Chapter 3 ("Hypsipyle and the Army at Nemea," pp. 49-66) is devoted to an analysis of an intertextual episode about Hypsipyle and Opheltes' death; Chapter 4- to the figure of Jocasta ("Jocasta," pp. 6781), and Chapter 5-to Oedipus ("iam pater est," pp. 83-97). The latter, as Simms convincingly shows, was treated by the poet in an especially original way. The figure of the old king of Thebes, which links the key episodes of the poem, undergoes a dramatic change from a defeated man who evokes sympathy, to a madman who finds joy in the destruction of his family and city - which to a reader familiar with the mythical tradition can be as surprising as it is shocking - to a mutilated old man, brought to the verge of degradation and helplessness. In the end, however, as Simms notes, the curse of seemingly meaningless Oedipus turns out equally as significant for the plot as the will of almighty Jupiter. In the next two chapters ("Portentous Ends," pp. 99-124; "hic imperat, ille minatur," pp. 125-142), the American scholar analyses the technique of constructing the figures of the main characters of the play: Polynices, Eteocles - two brothers with completely different psychological portraits, neither of whom was fit to wield powerand the eponymous generals of the expedition against Thebes (the figure of Creon's son, Menoeceus, is also discussed separately). These chapters, in which Simms slightly departs from his main method, valuably enrich his reflections with additional narrative strategies used by Statius. The last chapter of the work ("Theseus and the Concluding the Thebaid," pp. 143-159) is devoted to Theseus as a not altogether obvious and unambiguous saviour of Thebes from the power of tyrants.

It should be emphasised that Simms - and this is by no means obvious in works utilising fashionable and modern methods of analysis - shows good knowledge of Statius' poetry, which he freely discusses and interprets in the original (longer quotations are also accompanied by the author's own English translations). The author's reflections are well-reasoned. The bibliography and notes are perhaps not overly impressive (references to non-English publications are rare), but as the aim of the work was not to present the current state of research nor to exhaustively discuss all problems related to Statius' oeuvre, this is not a serious criticism. The reviewed book reflects contemporary trends in literary studies and is in many ways a novel and original reading of the Thebaid. As such, its publication should be met with joy.

Bartosz Jan Kołoczek http:/orcid.org/0000-0003-1401-0093 Jagiellonian University in Kraków 